\title{
Exploring archaeology's place in participatory European cultural landscape management: perspectives from the 'REFIT' project
}

\author{
Tom Moore and Gemma Tully
}

\section{Introduction: participatory landscapes}

The nature of landscape means it requires collective definition: international agreements emphasize the importance of community participation in environmental policy (United Nations 1992, Principle 10; Aarhus Convention, United Nations Economic Commission for Europe 1998). The European Landscape Convention (ELC) (Council of Europe (CoE) 2000) also emphasizes how landscapes are a 'common good', crucial to inhabitants' quality of life. Consequently, participatory engagement with landscapes has grown significantly (e.g. Jones and Stenseke 2011; Egoz et al. 2018). Participation and landscape definition often remain limited to professional stakeholders, however (CoE 2006, 173-8; Butler 2016; Conrad 2017), while heritage and archaeology often remain marginalized concerns (see e.g. Bateman and Balmford 2018). This is despite Europe's recognition of their importance to well-being and sense of place (CoE 2005).

Exploring the place of heritage in participatory landscape management is becoming increasingly relevant as Europe's landscapes face greater pressures from climate change, development and agricultural intensification. In this chapter we explore how heritage, specifically archaeology, has the potential to play a more central role in participatory understandings of landscape character and choices. Rather than engaging people with heritage for its own ends, archaeology can be fundamental to collective landscape management. 
We explore how taking biographical approaches (Kolen and Renes 2015) enables archaeology to contribute to arenas that engage stakeholders in social discourse. Focusing on the results of our own research project (REFIT), ${ }^{1}$ which examined the place of archaeology in the management of specific landscapes in England, France and Spain, we discuss the practicalities of situating archaeology in integrated landscape management. Many of our findings resonate with studies of landscape management elsewhere, allowing us to outline some key issues for European heritage agendas.

\section{The place of archaeology in landscape management}

The concept of 'cultural landscapes' as core to European landscape management (Fairclough and Rippon 2002) has meant that archaeology and heritage are widely regarded as integral to landscape character. Heritage remains, however, just one facet of complex landscape-related legislation (Spek 2017, 150 ), and the extent to which it figures in participatory processes is often unclear.

Archaeology is increasingly recognized as just one amongst many 'cultural ecosystems' (Hølleland et al. 2017), while it is considered that participation in heritage should focus less on preservation than on its role in stimulating engagement in landscape choices (Turner 2013). Developing from this perspective, REFIT explored how archaeological heritage is situated in landscape management and how it might figure in more effective participatory approaches. Focused on landscapes which included large Iron Age monuments, known as oppida, ${ }^{2}$ we examined four case studies: Bagendon and Salmonsbury (Cotswolds, England), Bibracte (Burgundy, France) and Ulaca (Ávila, Spain).

Oppida were chosen because they represent a particular challenge for heritage management. Their scale (often hundreds or thousands of hectares) yet unspectacular upstanding remains, alongside poor public recognition (Pierrevelcin and Guichard 2009), mean that their management balances heritage protection

1 Resituating Europe's First Towns: A case study in enhancing knowledge transfer and developing sustainable management of cultural landscapes: http://www .refitproject.com.

2 Oppida (sing. Oppidum) are major monuments dating from the third century BC to the first century $\mathrm{AD}$, potentially representing Europe's first urbanism (Moore 2017). 
with roles as working landscapes. Our case studies were situated in very different landscapes with contrasting management structures. Bibracte EPCC (établissement public de coopération culturelle) is a quasi-autonomous government body which manages 1004 ha around the oppidum; Salmonsbury oppidum is situated in a landscape owned and run by a wildlife charity; Bagendon and Ulaca are only subject to general planning and heritage legislation.

To minimize the privileging of one perspective, the project was coproduced with a range of stakeholder organizations with varying expertise: archaeological researchers, heritage managers, businesses, wildlife organizations, local government and landscape managers. Recognizing contested definitions of 'participation' (Egoz et al. 2018), we emphasized a broad concept of 'communities' (Smith and Waterton 2009), made up of diverse stakeholders and valuing different perspectives.

\section{Perceptions of landscapes and their management}

Before developing approaches to participation, it is essential to understand stakeholders' existing perceptions of landscapes and their management. Despite the ELC's emphasis on participation (Article 5c and 6B.c), how this is articulated varies (Conrad 2017). In our case studies, there was little evidence that stakeholder views had been incorporated within landscape management. Where this had taken place, it was through large-scale surveys (Powell and Clark 2003) rather than detailed engagement with stakeholders. To redress this, REFIT examined stakeholder perceptions using a variety of methods, including perception mapping, semi-structured interviews and online questionnaires (Moore and Tully 2018, 770-72). Despite their differing character, these approaches drew out issues common to all our case studies.

\section{Landscape values}

The interweave of natural and cultural factors in landscape character is widely recognized, but how this concept is communicated to, or resonates with, communities has received less attention. Surveys of stakeholders in our case studies revealed that only 20-30 per cent were aware of the term 'cultural landscape', with even some in management unfamiliar with the concept (Tully et al. 2019). Interviews revealed, however, that this concept resonates with stakeholders' views of landscape. The varied values our stakeholders associated with landscapes echoed other studies (e.g. Spencer 2011) in revealing that most recognize how landscapes are created by a combination of factors. The impli- 
cation is that concepts of cultural landscapes resonate with all stakeholders, but their underpinning philosophy needs better communication. Reflecting similar studies, stakeholders consistently valued heritage very highly (Tully et al. 2019). Despite frequently recognizing the pressures heritage can place on development and farming practice, most stakeholders did not see this as simply being to their detriment, but rather as requiring trade-offs in policies.

\section{Landscape biographies}

Participation needs to emerge from an understanding of the dynamic nature of landscapes (Kolen and Renes 2015). Our surveys revealed a generally limited appreciation of the ways in which landscape character had emerged and the choices concerning landscapes in the present. We found, instead, a tendency to view landscapes as static, or as places where change had only taken place recently. Many stakeholders also focused on specific narratives and narrow perceptions of significance. At Bibracte, for example, these focused on the landscape's Iron Age past, overlooking its more recent history. In all case studies there were strong perceptions of how the landscape should look; seen, for example, in the emphasis in the Cotswolds on the importance of dry-stone walls. Despite the strength of these views, there was little appreciation that these represent the retention (or replication) of specific landscape forms. Such perspectives are largely the product of management organizations' communication and focus on the significance of certain periods and particular landscape elements, which have contributed to a perceived regional aesthetic. These views of landscape character are, in effect, derived from a narrow sector of the population's ideas of value (Smith and Waterton 2009, 50), which come to be accepted as 'authentic', rather than emerging from more diverse participatory processes.

We also encountered a lack of awareness of how to engage with landscape decisions. At Bibracte, for example, despite a public presentation of alternative landscape futures (Guichard 2012), these were little known. This largely relates to a disconnect between residents' perceptions of the 'heritage landscape', focused on Bibracte, and their own 'lived' landscapes (Moore et al. 2020). Such dissonance may relate to the scale at which stakeholders conceive and experience landscape. Although there are a range of scales at which landscapes need to be understood and managed, REFIT's mapping exercises emphasized that most stakeholders engage with landscapes at a relatively small scale (cf. Spek 2017, 158). Within these landscapes, many stakeholders connect with elements of experienced heritage rather than with imposed ideas of significance (Smith and Waterton 2009). Using such heritage to connect stakeholders' participa- 
tion in landscape management with concepts of landscape biographies may be one way of bridging divisions between experience and management.

\section{Engaging management}

The numerous participatory approaches implemented since the ELC (Jones and Stenseke 2011; Egoz et al. 2018) might suggest that stakeholders are increasingly aware of landscape management. REFIT's surveys revealed, however, limited awareness of current strategies (Tully et al. 2019). In England, for example, despite living in close proximity to landscapes managed under stewardship, even landowning stakeholders knew little about what had happened and why (Moore and Tully 2018). This reflects the recognition that attempts in the UK to engage communities, through Local Landscape Character Assessments (Tudor 2014) and Neighbourhood Plans (DCLG 2011, Localism Act), have had limited impact and have seldom increased participation (Brookfield 2017, 402). The same appears true elsewhere; around Bibracte only around 25 per cent $(n=420)$ of stakeholders surveyed were aware of how the landscape is managed.

Interviews suggested this was not due to a lack of interest. Many participants noted that no one has ever told them how and why the landscape looks the way it does and that they do not know how to source this information. This lack of awareness relates significantly to how landscape information is presented: divided between aspects such as heritage, geology, ecology and agronomy. For some themes, information is not easily accessible and even where landscape organizations disseminated information on, for example, both wildlife and heritage, these were separated between different leaflets or noticeboards. Across all three countries there also remain structural divisions between 'cultural' and 'ecological' management, while the planning processes, in which they are embedded, disconnect the roles of many stakeholders (Stenseke 2016, 199). The impression is that, while individual participatory schemes are highly effective, a widespread impact on rural populations' participation in landscape planning has yet to be felt.

\section{Engaging stakeholders in landscape participation}

The themes which emerged from REFIT's surveys suggested two major issues. The first was the need to better equip stakeholders with an appreciation of the integrated and dynamic nature of cultural landscapes. The second was that, despite the value placed on heritage by stakeholders, it is seldom at the 
forefront of integrated management. Exploring how heritage might enhance participation in landscape management, we drew on two concepts. Ideas of landscape biographies (Kolen and Renes 2015) were useful in addressing lacunae in current presentations of cultural landscapes. Meanwhile, ideas of the 'landscape as commons' (Ostrom 1990; Le Roy 2016) were drawn on in developing communities' role in decision-making.

Biographical approaches to the landscape (Kolen and Renes 2015) enable stakeholders to place themselves in a longue durée of landscape change. Archaeology, rather than re-treading specific narratives, has the potential to facilitate such biographies, stimulating stakeholders' choices about landscape change and moving beyond dichotomies of preservation versus development. REFIT undertook this by coproducing guides with non-heritage stakeholders. These leaflets, digital downloads and interactive web guides (including a suite of videos) $)^{3}$ combined information on archaeology, ecology and modern land use. They emphasized the importance of inhabitants' places in landscape biographies, incorporating perspectives from varied stakeholders. To ensure that neither local resident nor managerial perspectives were privileged, both were included, emphasizing knowledge exchange and the multiplicity of values. At relatively low cost, these allowed sustainable presentations of cultural landscapes, directed towards both local and external stakeholders.

We also explored how archaeology might facilitate arenas for communities to engage in landscape choices. Recognizing stakeholders' differing understandings of heritage, but also the value they place on it, participation needs to emerge from stakeholders' interests. To do this, at Bibracte, local stakeholders were engaged through landscape workshops to coproduce assessments of landscape character (Chazelle 2017). These revealed residents' interest in the region's rural trackways (Darroux 2017). Tracing these, and considering their history, current use and future preservation, acted as a shared interest amongst diverse stakeholders, providing a gateway into broader reflection on the landscape's future. This approach echoes other studies which demonstrate how heritage, especially that which structures the landscape (trackways: Le Dû-Blayo et al. 2015; irrigation networks: Martín Civantos and Bonet García 2015; waterways: Vallerani and Visentin, this volume) has the potential to unite the interests of varied stakeholders. In the Cotswolds, farming and ecology stakeholders were engaged through participatory events using the archaeological technique of augering (Figure 5.1; Tully and Allen 2018). Developing from stakeholders' existing interests in soils and species in relation to land use, and looking at past

Guides for these landscapes can be found at: http://www.refitproject.com. 
human impact on landscape, these acted as a stimulus to reflect on contemporary land uses. In all these approaches, stimulating physical engagement with the landscape provided a powerful method for reflection on wider issues.

To ensure greater reach, larger engagement events were necessary. Open days at Salmonsbury, Ulaca and Bibracte included workshops and presentations by experts from different disciplines, focusing on issues of landscape change. Around Bibracte, holding these at local farms engaged stakeholders in their own environment, breaking down barriers between 'expert' and 'lived' spaces. These events were coproduced to ensure heritage, ecology and agronomy were not presented as distinct; they used the archaeology of the oppida not as the focus but as hubs for dialogue.

Addressing these concerns, REFIT suggested that enhancing participation might best be achieved through the use of existing 'landscape leadership'. These are stakeholders who, through their existing connections to a range of other stakeholders, provide a sustainable participatory focus in the landscape. In REFIT's case studies, such 'leaders' varied. From its focus on heritage, Bibracte is developing as a space which connects national and regional agencies, academics and local communities (Guichard 2017). At Salmonsbury, the Wildlife Trust has a diverse membership and wide-ranging landscape connections. Where no obvious leader exists, REFIT echoed some other studies (García Martín et al. 2016, 51) in realizing that the social capital of individual farmers or politicians is key to facilitating integration. This was true in the Ávila case study landscape, for example, where the local mayor acted as the nexus for stakeholder interaction. The landscape role or specialism of these 'leaders' (ecology, heritage management, and so on) is less important than providing a focus to facilitate engagement.

\section{Discussion: challenges for archaeology's place in participatory landscapes}

Ensuring that management is participatory is now widely recognized as important if landscapes are to be managed sustainably (Reed 2008). The practicalities of participation and ensuring well-informed stakeholders remain challenging, however. Despite the small scale of the REFIT project, many of its findings resonate with other studies (e.g. Hercules n.d.), allowing us to point to some key areas which may improve heritage's role in landscape management. These are outlined below. 


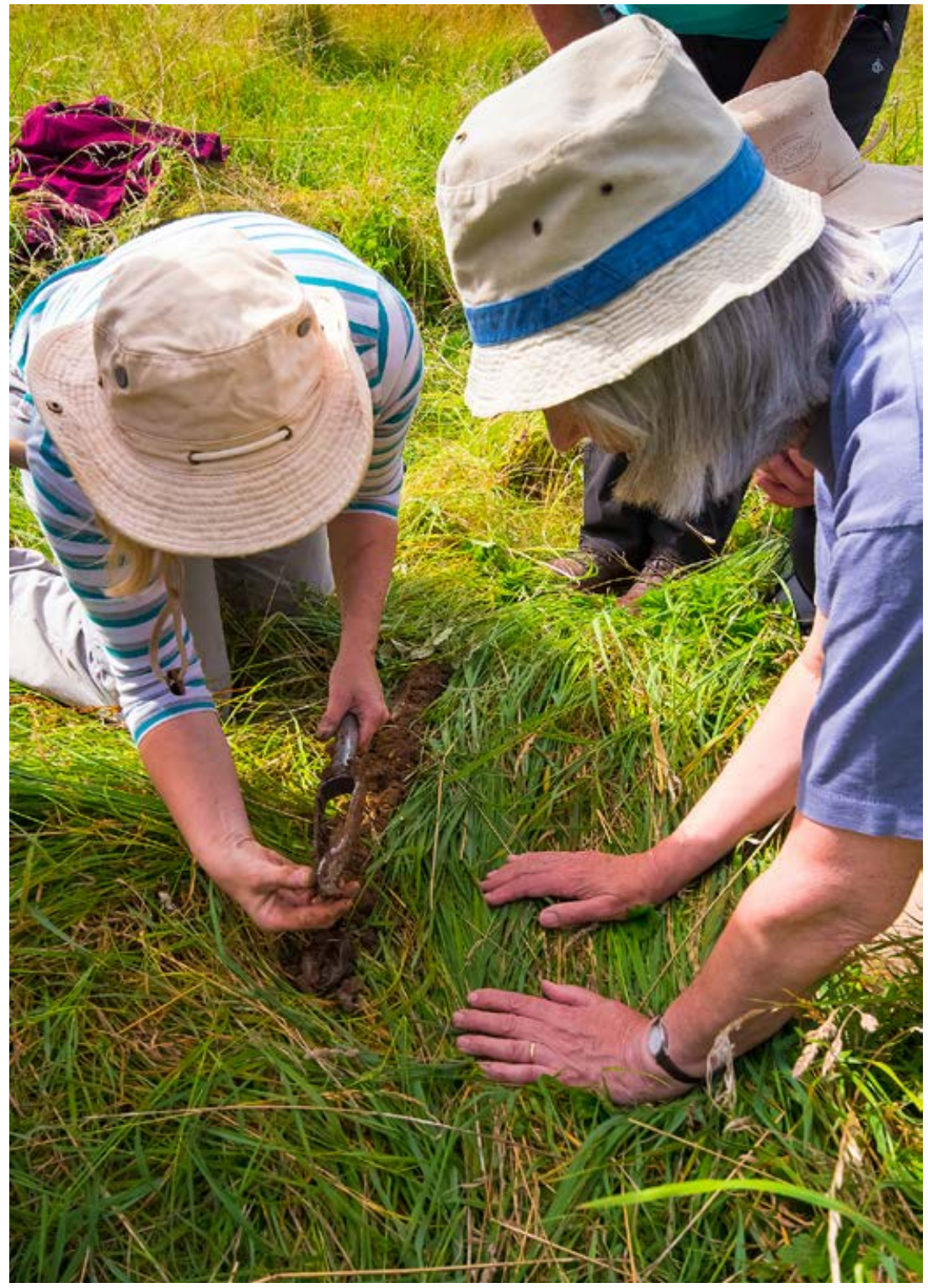

Source: Image courtesy of Mike Boyes.

Figure 5.1 Participatory augering workshop at Salmonsbury (Greystones Farm), 2017 


\section{Improving knowledge exchange}

REFIT revealed that greater efforts to explain existing strategies are required to foster participation. Concerns that stakeholders are not interested in landscape management were not borne out by REFIT's surveys; instead, these encountered a widespread wish to engage in decision-making (cf. Selman 2004). As some governments align farming subsidies towards 'public money for public goods' (DEFRA 2018), the desire to understand how landscapes are managed seems likely to increase. Dissemination of information on existing strategies needs to be improved, therefore. This might be through enhanced web portals, but dissemination is likely to be unsuccessful without forums for knowledge exchange. Building on existing 'landscape leaders' may be one way of fostering more active stakeholders while ensuring sustainable participation.

\section{Ensuring sustainable participation}

There is increasingly good practice in participatory integrated management (e.g. García Martín et al. 2016; Bieling and Plieninger 2017), yet many strategies still include relatively little participation beyond management or farming stakeholders. Concepts of landscapes as 'commons' address these concerns but, in practice, power imbalances between stakeholders must be mitigated, while recognizing that other stakeholders (tourists, the general public, external interest groups) are essential contributors (Jones 2011, 34). As the UK's attempts at increased localism reveal, without facilitation such approaches are likely to be skewed to particular stakeholders, increasing rather than reducing dissatisfaction with management (Brookfield 2017). Championing a bottom-up approach may work in landscapes where traditions of communal decision-making exist (Le Roy 2016), but the same may not be true elsewhere. Active organizations, such as heritage managers or wildlife organizations, acting as 'landscape leaders', may play key roles in ensuring and diversifying participation. There remains, however, a need for governments to develop mechanisms for engagement, such as through more participatory Landscape Character assessments, like those in the UK (Butler 2016), and funding for partnership-based projects.

\section{Heritage and archaeology as drivers of landscape biographies}

The widespread recognition that cultural heritage is valued across the stakeholder spectrum suggests that it has the potential to act as a focus for connecting stakeholders. However, its role in integrated management is often limited. Heritage stakeholders need to emphasize that it is an essential element of any landscape biography, not an optional extra. To do so, heritage professionals 
need to develop coproductive relationships with other stakeholders to ensure it becomes an active element of landscape discourse. Archaeology, in particular, has remained surprisingly slow to move away from models of 'community archaeology' based on simply engaging people in stories about the past (Tully and Allen 2018, 3). Archaeology, however, has significant potential to act as a lever in creating landscape biographies. Its longue durée perspective on landscapes allows communities to contextualize future changes. At the same time, the materiality and physicality of archaeology enable physical landscape engagement rather than passive reflection, in our experience often stimulating more wide-ranging discourse. Without exploring its potential, archaeology remains in danger of leaving landscapes to other disciplines (Fairclough and Rippon 2002), to the detriment of landscapes' vibrancy and sustainability.

\section{Situating experts as stakeholders}

Through coproduction with existing landscape leaders, there are pathways for ensuring archaeology is not perceived as a marginal 'cultural ecosystems service'. This includes raising the profile of archaeological heritage but also, more crucially, situating archaeology as integral to discourse on landscape biographies. In an era when experts are frequently regarded suspiciously (Pendlebury and Veldpaus 2018, 448), breaking down distinctions between stakeholder roles facilitates, rather than imposes, definitions of landscape (Butler 2016), and may increase participation. Situating specialists, such as archaeologists, as fellow stakeholders rather than managers may be one way of fostering more inclusive and less 'top-down' approaches as part of a move to more integrated and sustainable European landscapes.

\section{Acknowledgements}

We are very grateful to REFIT's co-investigators, Vincent Guichard and Jesus Alvarez-Sanchis, the other project researchers (Jonhattan Vidal, Jesus Rodríguez, Chiara Pai and Elodie Delhommeau) and our partner organizations, as well as local residents, for their support and input into the project. This research was funded by the European Union's Joint Programme Initiative on Cultural Heritage through the research agencies of France (ANR), Spain (Mineco) and the UK (AHRC grant: AH/N504403/1). 


\section{References}

Bateman, I. and B. Balmford (2018), 'Public funding for public goods: A post-Brexit perspective on principles for agricultural policy', Land Use Policy, 79, 293-300.

Bieling, C. and T. Plieninger (eds) (2017), The Science and Practice of Landscape Stewardship, Cambridge: Cambridge University Press.

Brookfield, K. (2017), 'Getting involved in plan-making: Participation in neighbourhood planning in England', Environment and Planning C: Politics and Space, 35 (3), 397-416.

Butler, A. (2016), 'Dynamics of integrating landscape values in landscape character assessment: the hidden dominance of the objective outsider', Landscape Research, 41 (2), 239-52.

Chazelle, Cl. (2017), Bibracte Mont-Beuvray. Gestion du Grand Site et de ses territoires. Eléments de diagnostic paysager, Clermont-Ferrand: Atelier Claude Chazelle, accessed 1 May 2018 at http://www.bibracte.fr/media/bibracte/163210 -2017_chazelle_diagnostic_paysager.pdf.

CoE (Council of Europe) (2000), European Landscape Convention, accessed October 2016 at https://rm.coe.int/CoERMPublicCommonSearchServices/DisplayDCTMContent ?documentId=09000016802f80c6.

CoE (Council of Europe) (2005), 'Council of Europe Framework Convention on the Value of Cultural Heritage for Society (Faro)', accessed October 2016 at https://rm .coe.int/1680083746.

CoE (Council of Europe) (2006), Landscape and Sustainable Development. Challenges for the European Landscape Convention, Strasbourg: Council of Europe.

Conrad, E. (2017), 'Human and social dimensions of landscape stewardship', in C. Bieling and T. Plieninger (eds), The Science and Practice of Landscape Stewardship, Cambridge: Cambridge University Press, 38-53.

Darroux, C. (2017) 'Journée participative: paysage et patrimoine à Glux en Glenne 11 juillet 2017', accessed 10 May 2021 at https://reflaction.hypotheses.org/386.

DEFRA (Department for Environment, Food and Rural Affairs) (2018), 'A Green Future: Our 25 Year Plan to Improve the Environment', accessed August 2018 at http://www.gov.uk/government/publications.

DCLG (2011), Localism Act 2011, Department for Communities and Local Government, accessed July 2021 at https://www.legislation.gov.uk/ukpga/2011/20/contents.

Egoz, S., K. Jørgensen and D. Ruggeri (2018), Defining Landscape Democracy. A Path to Spatial Justice, Cheltenham, UK and Northampton, MA, USA: Edward Elgar Publishing.

Fairclough, G. and S. Rippon (eds) (2002), Europe's Cultural Landscape: Archaeologists and the Management of Change, Brussels: Europae Archaeologiae Consilium.

García Martín, M., C. Bieling, A. Hart and T. Plieninger (2016), 'Integrated landscape initiatives in Europe: Multi-sector collaboration in multi-functional landscapes', Land Use Policy, 58, 43-53.

Guichard, V. (2012), 'An example of integrated management of a heritage site: Bibracte-Mont Beuvray (Burgundy, France)', in C. Gambardella (ed.), Less More Architecture Design Landscape. Le Vie dei Mercanti. X forum Internazionale di Studi, Napoli: La sucuola di Pitagora (Fabbrica della Conoscenza 16), pp. 120-3.

Guichard, V. (2017), 'Bibracte: le paysage au c'ur du projet de site/Bibracte: Die Landschaft im Zentrum des Projekts der archäologischen Stätte’, in C. Dunning and 
E. Dunning (eds), Paysages entre archéologie et tourisme / Landschaften zwischen Archäologie und Tourismus, Bienne: ArchaeoTourism, pp. 102-13.

Hercules (n.d.), 'The landscape approach: Recommendations towards landscape-centred policies', accessed June 2018 at http://www.hercules-landscapes.eu/tartalom/ publications/articles_5.pdf.

Hølleland, H., J. Skrede and S.B. Holmgaard (2017), 'Cultural heritage and ecosystem services: a literature review', Conservation and Management of Archaeological Sites, 19 (3), 210-37.

Jones, M. (2011), 'European landscape and participation: rhetoric or reality?', in M. Jones and M. Stenseke (eds), The European Landscape Convention: Challenges of Participation, Dordrecht: Springer, 27-44.

Jones M. and M. Stenseke (eds) (2011), The European Landscape Convention: Challenges of Participation, Dordrecht: Springer.

Kolen, J. and H. Renes (2015), 'Landscape biographies: key issues', in J. Kolen, H. Renes and R. Hermans (eds), Landscape Biographies. Geographical, Historical and Archaeological Perspectives on the Production and Transmission of Landscapes, Amsterdam: Amsterdam University Press, pp. 21-48.

Le Dû-Blayo, L., V. Van Tilbeurg, C. Thenail and D. Le Coeur (2015), 'Paths that trace a territorial thought through the landscape', in Y.Luginbühl, P. Howard and D. Terrasson (eds), Landscape and Sustainable Development: The French Perspective, London: Routledge, pp. 47-61.

Le Roy, E. (2016), 'Des communs “à double révolution”', Droit et Société, 94, 603-24.

Martín Civantos, J.M. and M.T. Bonet García (2015), 'MEMOLA project. Mediterranean Mountainous Landscapes: an historical approach to cultural heritage based on traditional agrosystems', European Journal of Post-Classical Archaeologies, 5, 347-56.

Moore, T. (2017), 'Alternatives to urbanism? Reconsidering oppida and the urban question in Late Iron Age Europe', Journal of World Prehistory, 30 (3), 281-300.

Moore, T. and G. Tully (2018), 'Connecting landscapes: examining and enhancing the relationship between stakeholder values and cultural landscape management in England', Landscape Research, 43, 769-83.

Moore, T., V. Guichard and J. Álvarez Sanchís (2020), 'The place of archaeology in integrated cultural landscape management. A case study comparing landscapes with Iron Age oppida in England, France and Spain', Journal of European Landscapes, 1, $9-28$.

Ostrom, E. (1990), Governing the Commons: The Evolution of Institutions for Collective Action, Cambridge: Cambridge University Press.

Pendlebury, J. and L. Veldpaus (2018), 'Heritage and Brexit', Planning Theory and Practice, 19 (3), 448-53.

Pierrevelcin, G. and V. Guichard (2009), 'Protection et accessibilité des oppida. Bilan de la visite de quelques sites', in I. Benková and V. Guichard (eds), Gestion et Présentation des Oppida: Un Panorama Européen, Glux-en-Glenne: Bibracte Monograph 15, 15-26.

Powell, J.R. and M. Clark (2003), Cotswold AONB Survey 2002: Your Ideas, Concerns and Aspirations, Project Report. Cheltenham: Cotswolds Conservation Board.

Reed, M.S. (2008), 'Stakeholder participation for environmental management: a literature review', Biological Conservation, 141 (10), 2417-31.

Selman, P. (2004), 'Community participation in the planning and management of cultural landscapes', Journal of Environmental Planning and Management, 47 (3), 365-92. 
Smith, L. and E. Waterton (2009), Heritage, Communities and Archaeology, Bloomsbury: London.

Spek, T. (2017), 'The future of the past', in C. Bieling and T. Plieninger (eds), The Science and Practice of Landscape Stewardship, Cambridge: Cambridge University Press, pp. 148-63.

Spencer, N. (2011), 'Participation within the landscape of the river Dart catchment, Devon, England', in M. Jones and M. Stenseke (eds), The European Landscape Convention: Challenges of Participation, Dordrecht: Springer, pp. 239-60.

Stenseke, M. (2016), 'Integrated landscape management and the complicating issue of temporality', Landscape Research, 41 (2), 199-211.

Tudor, C. (2014), An Approach to Landscape Character Assessment, Sheffield: Natural England.

Tully, G. and M. Allen (2018), 'Participatory augering: a methodology for challenging perceptions of archaeology and landscape change', Public Archaeology, 16 (3-4), 191-213.

Tully, G., C. Piai, J. Rodríguez Hernández and E. Delhommeau (2019), 'Understanding perceptions of cultural landscapes in Europe: A comparative analysis using "oppida" landscapes', The Historic Environment: Policy \& Practice, 10 (2), 198-223.

Turner, S. (2013), 'Landscape archaeology', in P. Howard, I. Thompson, E. Waterton and M. Atha (eds), The Routledge Companion to Landscape Studies, London: Routledge, pp. 155-65.

UNECE (1998), UNECE Convention on Access to Information, Public Participation in Decision-making and Access to Justice in Environmental Matters (Aarhus Convention), accessed July 2021 at https://unece.org/environment-policy/public -participation/aarhus-convention/introduction.

United Nations (1992), The Rio Declaration on Environment and Development, United Nations Conference on Environment and Development, Rio de Janeiro, Brazil, 3-14 June, accessed July 2021 at https://www.un.org/en/conferences/environment/ rio1992. 
Tom Moore and Gemma Tully - 9781788974639 Downloaded from PubFactory at 04/26/2023 01:04:30PM via free access 